\title{
Effect of Heat Treatment on the Damping Capacity of Austempered Ductile Cast Iron
}

\author{
Chang-Yong Kang ${ }^{1}$, Jang-Hyun Sung ${ }^{2}$, Gwang-Ho Kim ${ }^{3}$, Byoung-Suhk Kim ${ }^{3}$ and Ick-Soo Kim ${ }^{3, *}$ \\ ${ }^{1}$ Division of Advanced Materials Engineering, Pukyong National University, Busan 608-739, Korea \\ ${ }^{2}$ Department of Advanced Materials Engineering, Dong-a University, Busan 604-714, Korea \\ ${ }^{3}$ Department of Functional Machinery and Mechanics, Shinshu University, Nagano 386-8567, Japan
}

We investigated the effects of austempering and subzero treatment on the damping capacity in austempered ductile cast iron. The damping capacity of austempered ductile cast iron was rapidly increased by the austempering treatment, although it was not affected by the austempering temperature or time. After subjecting the austempered ductile cast iron to subzero treatment, the austenite was transformed into martensite, and the volume fraction of the martensite increased as the subzero treatment temperature decreased. The subzero treatment sharply increased the damping capacity of the austempered ductile cast iron. However, the damping capacity gradually increased as the subzero treatment temperature decreased. By increasing the subzero treatment time, the damping capacity rapidly increased until the subzero treatment time reached 30 min, after which it increased gradually. By increasing the volume fraction of the martensite, the damping capacity was rapidly increased until the volume fraction was 5\%, beyond which it increased gradually. [doi:10.2320/matertrans.MRA2008427]

(Received November 20, 2008; Accepted March 17, 2009; Published May 13, 2009)

Keywords: subzero treatment, damping capacity, retained austenite, ductile cast iron, $\varepsilon$ martensite, austempering

\section{Introduction}

Austempered ductile cast irons prepared by austempering treatment of ductile cast irons retain a relatively significant amount of the austenite microstructures, except for the bainite microstructure. Because the mechanical properties essentially depend on both bainite and retained austenite microstructures, austempered ductile cast irons have very high strength and excellent toughness. Therefore, they have been used as an economical substitute for forgings. In addition, austempered ductile cast irons allow easy preparation of complicated machine parts. Thus, they are used extensively for many structural applications in the automotive, defense, earth-moving machinery, railroad, and similar industries. ${ }^{1,2)}$ The damping capacity of austempered ductile cast iron possessing excellent strength and toughness can be affected not only by the bainite microstructure formed by the austempering treatment but also by the retained austenite microstructure, which has an internal twin microstructure. This microstructure is a retained microstructure that does not transform into the bainite microstructure when the ductile cast iron is austenitized. Therefore, the damping capacity can be varied by changing the austempering treatment conditions such as austempering temperature and time. Because of its poor stability, the retained austenite microstructure can be transformed into a martensite microstructure not only by plastic working (for example, rolling and forging ${ }^{3)}$ ) but also by subzero treatment that permits the austenite-to-martensite transformation by lowering the temperature below the Ms point. ${ }^{4)}$ It is therefore believed that the damping capacity of austempered ductile cast iron can be dramatically varied by changing the subzero treatment conditions. In this work, we attempt to study the effects of austempering and subzero treatments on the damping capacity of austempered ductile cast iron. We explored various conditions of austempering and subzero treatments of ductile cast iron.

*Corresponding author, E-mail: kim@shinshu-u.ac.jp
Table 1 Chemical composition of specimen (mass\%).

\begin{tabular}{cccccccc}
\hline $\mathrm{Fe}$ & $\mathrm{C}$ & $\mathrm{Si}$ & $\mathrm{Mn}$ & $\mathrm{P}$ & $\mathrm{S}$ & $\mathrm{Mg}$ & $\mathrm{Cu}$ \\
\hline Bal. & 3.40 & 2.50 & 0.21 & 0.01 & 0.01 & 0.05 & 0.15 \\
\hline
\end{tabular}

Table 2 Microstructural analysis of as cast ductile cast iron.

\begin{tabular}{ccccc}
\hline Struc. & Ferrite $(\%)$ & Perlite $(\%)$ & Graphite $(\%)$ & $\begin{array}{c}\text { Mean diameter of } \\
\text { graphite module }(\mu \mathrm{m})\end{array}$ \\
\hline A & 67.9 & 22.2 & 9.8 & 17.8 \\
\hline
\end{tabular}

\section{Experimental Methods}

\subsection{Materials and thermal treatment}

Each specimen used in this study was dissolved in a cupola and cast in the form of a Y-block to yield an ingot, which was then subjected to testing. The specimens were sphere-shaped (>93\%). Tables 1 and 2 illustrate the chemical composition and microstructural data of the specimen, respectively. The austempering treatment was carried out as follows:

(1) The specimen was austenitized in a salt bath at $1153 \mathrm{~K}$ for $1 \mathrm{~h}$.

(2) It was immediately added to a salt bath that was set to the temperature range of $623-823 \mathrm{~K}$.

(3) The specimen was maintained at this temperature range for 10-120 min and then air-cooled.

(4) The subzero treatment was carried out by quenching the specimens until their temperatures decreased to 233, 203 and $77 \mathrm{~K}$.

(5) The specimens were maintained at each temperature for 30-120 min. Each lower temperature was achieved by pure or mixture of methanol, dry ices, and liquid nitrogen.

\subsection{Microstructural analysis}

The microstructures of as-cast ductile cast iron and austempering and subzero-treated ductile cast iron were 
examined by optical microscopy (OM) and scanning electron microscopy (SEM). The austenite-to-martensite transformation by subzero treatment was studied using transmission electron microscopy (TEM) with an acceleration voltage of 200 kV (JEM 2010; JEOL Ltd., Tokyo, Japan). The specimen, which was $80-\mu \mathrm{m}$ thick, was jet-polished for TEM analysis. The quantitative analysis of the microstructure was performed using an image analyzer.

\subsection{X-ray diffraction (XRD) analysis}

We used XRD analysis to estimate the extent of the transformation of the austenite into martensite when austempered ductile cast iron was subjected to subzero treatment. ${ }^{5)}$ XRD was conducted using monochromatic Mo-K $\alpha$ radiation at a scanning rate of $2 \theta=1.0^{\circ} / \mathrm{min}$. The volume fraction of the crystalline peaks corresponding to each phase was determined by the direct comparison method using the integrated intensities of martensite (10-11) and austenite (200) calculated with the following equations: $:$,7)

$$
\begin{aligned}
& V_{\mathrm{m}}+V_{\gamma}=1 \\
& \frac{I_{\gamma}}{I_{\mathrm{m}}}=\frac{R_{\gamma}}{R_{\mathrm{m}}} \times \frac{V_{\gamma}}{V_{\mathrm{m}}} \\
& R=\frac{1}{v^{2}} \cdot|F|^{2} \cdot P \cdot L \cdot e^{-2 \mathrm{M}}
\end{aligned}
$$

where $V$ is volume fraction, $I$ is the integrated intensity of specific diffraction line, and the subscript indices $m$ and $\gamma$ denote martensite and austenite, respectively. $R$ is determined by the following terms: $v$ is the unit cell volume, $F$ is the structure factor, $P$ is the multiplicity factor, $L$ is the Lorentz polarization factor, and $e^{-2 \mathrm{M}}$ is the temperature factor. As for the factors in eq. (3), we assigned the values suggested by Cullity. ${ }^{8}$ )

\subsection{The damping capacity measurement}

The damping capacity is the measure of a material's ability to dissipate elastic strain energy during mechanical vibration or wave propagation. When properly used in a structural application, this property allows undesirable noise and vibration to be passively attenuated and removed to the surroundings as heat. ${ }^{9)}$ To measure the vibration damping capacity, the specimen with dimensions of $1.0 \times 10 \times$ $120 \mathrm{~mm}$ (thickness $\times$ width $\times$ length) was machined using wire electrical discharge machining (EDM), followed by austempering and then subzero treatment. The damping capacity was measured with a flexural internal friction measurement machine (IFT-1500; ULVAC Inc., Japan) at room temperature. The specimen was placed parallel to two electrodes in a three-line arrangement without contacting the electrodes. One electrode supplied the vibration to the specimen; the other one received the vibration from the specimen. In one test, after steady-state vibration with a strain amplitude of about $2 \times 10^{-6}$ and a frequency of about $780 \mathrm{~Hz}$, the driving signal was turned off and a free-decay curve was recorded by a computer through a high-speed analogue-digital converter. ${ }^{10)}$ The vibration amplitude of the specimen was measured by means of an optical sensor during the whole vibration attenuation process. The damping was shown by the logarithmic decrement $(\delta)$ defined as follows:

$$
\delta=1 / n \ln \left(A_{0} / A_{n}\right)
$$

where $n$ is the vibration cycle and $A_{0}$ and $A_{n}$ represent the vibration amplitudes of the initial and $n$th cycles, respectively. The damping capacity can be calculated from the decay of the vibration.

\section{Results and Discussion}

\subsection{Microstructural analysis}

Figure 1 shows the optical micrographs of (a) as-cast and (b) austempering-treated specimens. As illustrated in Fig. 1(a), spherical graphite was observed in the pearlite and ferrite microstructures. In fact, more than $93 \%$ of the observed graphite structures were sphere-shaped, and bull'seye microstructures characteristic of ductile cast iron were also observed. Figure 1(b) shows that the matrix was transformed into a bainite microstructure by the austempering treatment. Figure 2 shows the SEM micrograph of the austempered ductile cast iron obtained by subzero treatment at $77 \mathrm{~K}$, which exhibits the same bainite microstructure as the austempering-treated specimen. When the austemperingtreated specimen is subjected to further subzero treatments, the retained austenite will be transformed into martensite. ${ }^{4)}$ However, such transformation into martensite was not
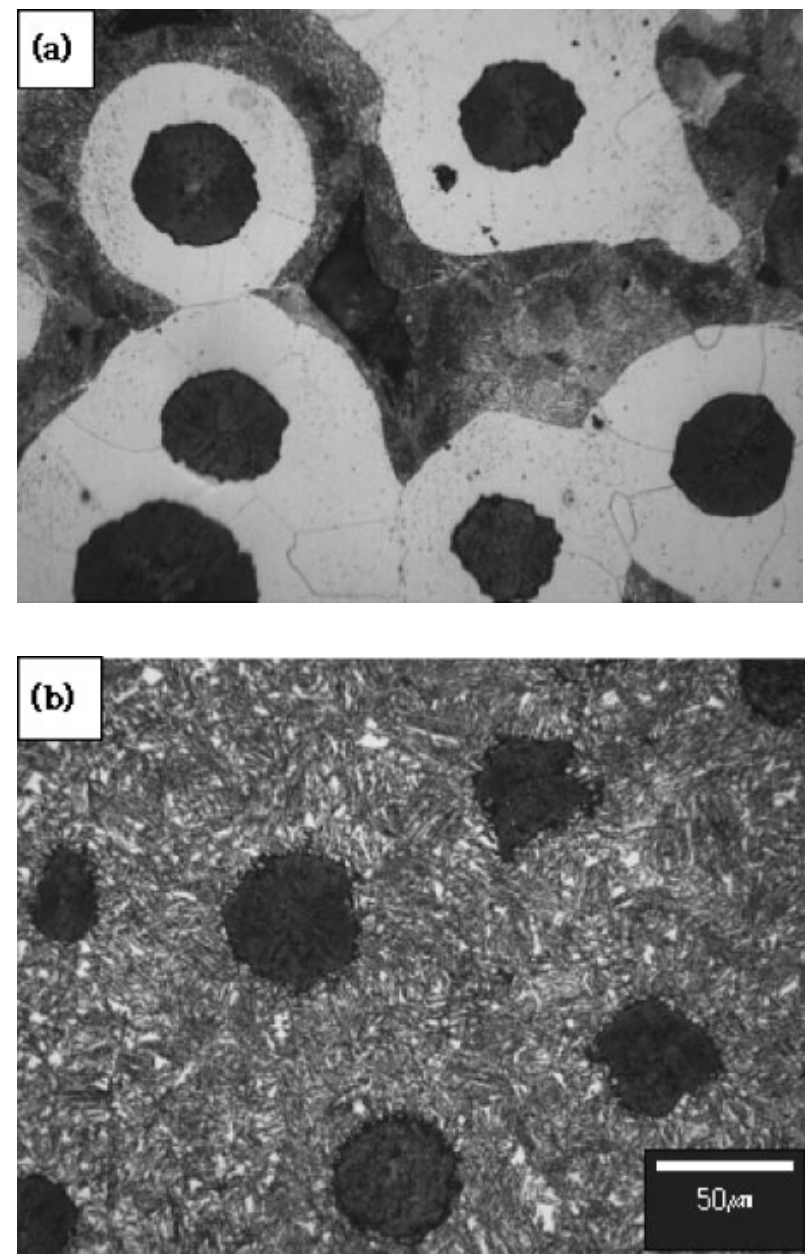

Fig. 1 Optical micrographs of ductile cast iron (a) as cast and (b) austempering treated. 


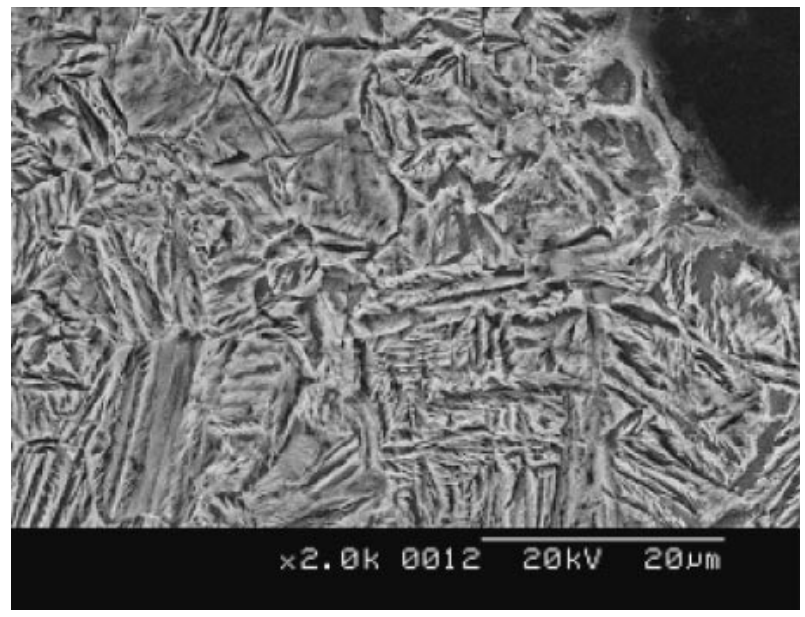

Fig. 2 SEM micrograph of austempered ductile cast iron obtained by subzero treatment at $77 \mathrm{~K}$. observed in the SEM micrograph. Figure 3 shows the TEM micrograph of the retained austenite obtained by austempered treatment at $673 \mathrm{~K}$ for $30 \mathrm{~min}$. First, the specimen used for the TEM measurements was austenitized at $1153 \mathrm{~K}$ for $1 \mathrm{~h}$; then, it was subjected to austempering treatment in a salt bath maintained at $273 \mathrm{~K}$ for $30 \mathrm{~min}$. The diffraction pattern taken from the selected area (shown as a circle) in Fig. 3(a) shows that some of the austenite was maintained without being transformed into bainite microstructures by the austempering treatment.

\subsection{Effect of subzero treatment on microstructure}

Figure 4 shows the TEM micrograph of the martensite obtained by subzero treatment at $77 \mathrm{~K}$ after the austempering treatment. The specimen used for the TEM measurement was austenitized at $1153 \mathrm{~K}$ for $1 \mathrm{~h}$ and then subjected to austempering treatment in a salt bath maintained at $673 \mathrm{~K}$ for $30 \mathrm{~min}$, followed by a subzero treatment at $77 \mathrm{~K}$ for
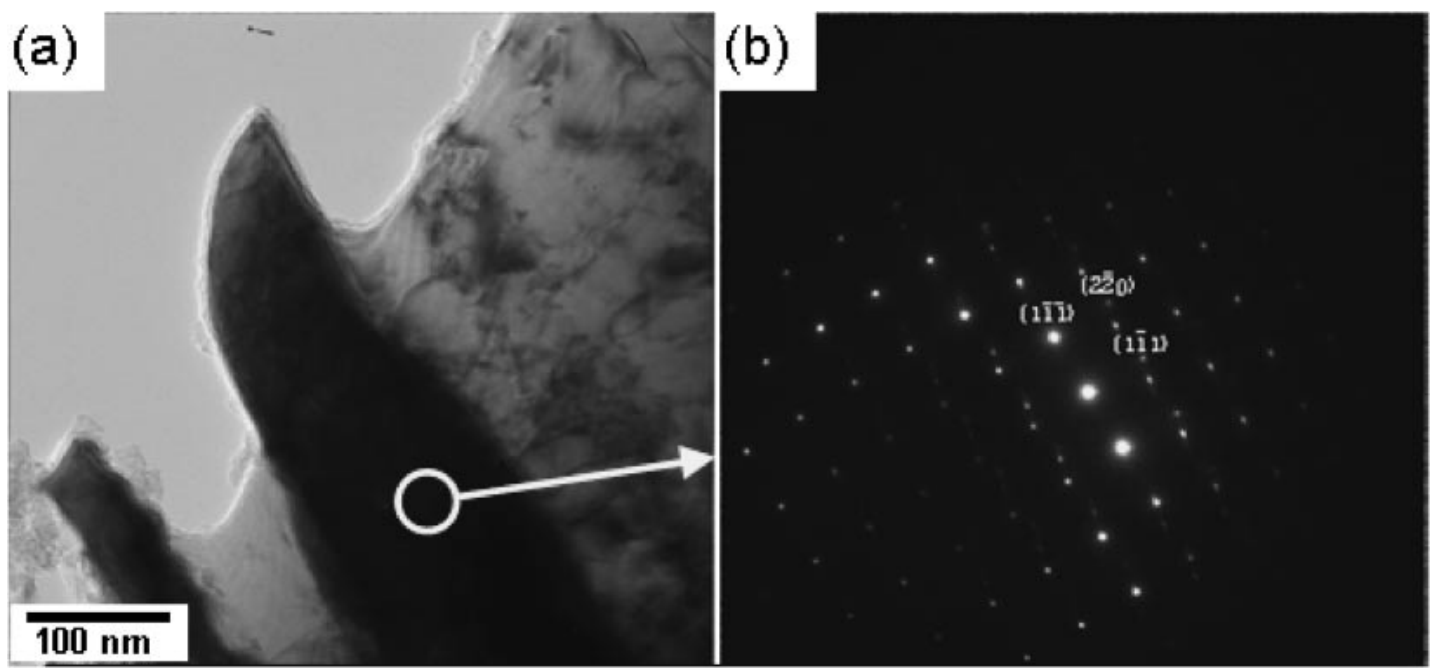

Fig. 3 TEM micrograph of the retained austenite obtained by austempering treatment at $673 \mathrm{~K}$ for 30 min., (a) Bright field image, (b) Diffraction (indexed) pattern.
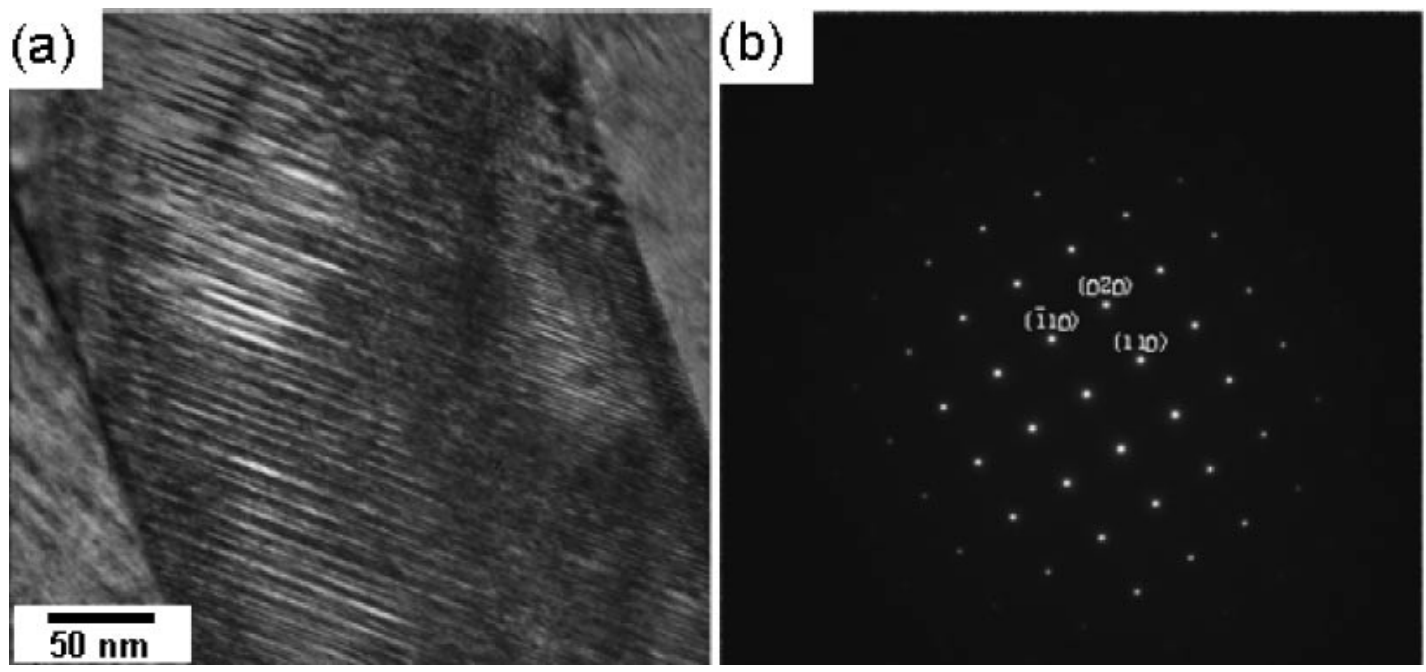

Fig. 4 TEM micrograph of the martensite obtained by subzero treatment at $77 \mathrm{~K}$ after austempering treatment, (a) Bright field image, (b) Diffraction (Indexed) pattern. 


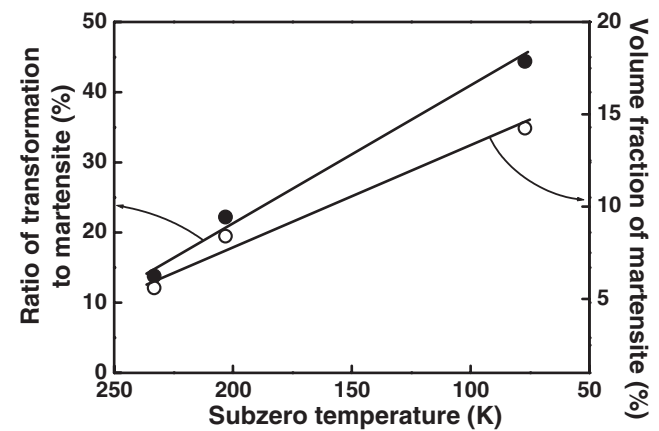

Fig. 5 Effect of subzero treatment temperature on the transformation into martensite in austempered ductile cast irons.

30 min. Figure 4(a) represents the bright field image, and Fig. 4(b) represents the diffraction (indexed) pattern. The diffraction pattern of the microstructure with the banded shape in Fig. 4(a) shows that some of the retained austenite was transformed into martensite by the subzero treatment. Figure 5 shows the effect of subzero treatment temperature on the transformation into martensite in austempered ductile cast iron. Some of the retained austenite was transformed into martensite by the subzero treatment; this observation coincided with the results of the TEM analysis. The lower the subzero treatment temperature, the greater was the degree of transformation into martensite. For instance, when the subzero treatment temperature was $233 \mathrm{~K}$, ca. $13 \%$ of the retained austenite was transformed into martensite, and ca. $5 \%$ of martensite was formed. However, when the subzero treatment temperature was $77 \mathrm{~K}$, ca. $43 \%$ of the retained austenite was transformed into martensite, and more than $13 \%$ of martensite was formed.

\subsection{Effect of austempering treatment on damping capacity}

Figure 6 shows the effect of the austempering treatment temperature on the damping capacity in austempered ductile cast iron. Compared to as-cast ductile cast iron, austempered ductile cast iron showed drastically decreased damping capacity. On the other hand, the damping capacity of the austempered ductile cast iron was not affected by austempering treatment temperature and showed a similar value. Thus far, it had been considered that austempering treatment caused a decrease in damping capacity mainly because of the formation of austenite and exhaustion of the vibration energy on account of plasticity or plastic flow occurring in the interface between graphite and ferrite microstructures in the ductile cast iron. ${ }^{11)}$ Because ductile cast iron is composed of soft ferrite microstructures located around spherical graphite, plastic flow occurred more easily in the interface between graphite and ferrite microstructures, thereby resulting in a rather higher damping capacity. On the other hand, the ferrite and pearlite microstructures of austempered ductile cast iron that together constitute a matrix microstructure can be transformed into bainite microstructures by austempering treatment. Such microstructural transformation of ferrite and pearlite into bainite was previously reported by Kang. ${ }^{12)}$ Because the bainite microstructure has a higher hardness value than the austenite microstructure, it is difficult for

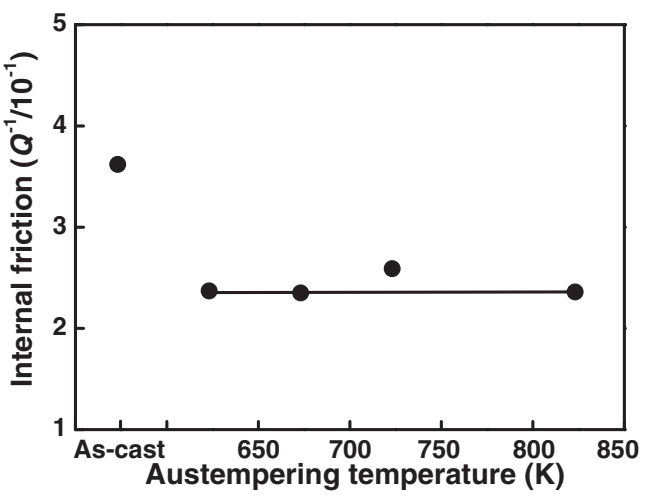

Fig. 6 Effect of austempering treatment temperature on the damping capacity in austempered ductile cast irons.

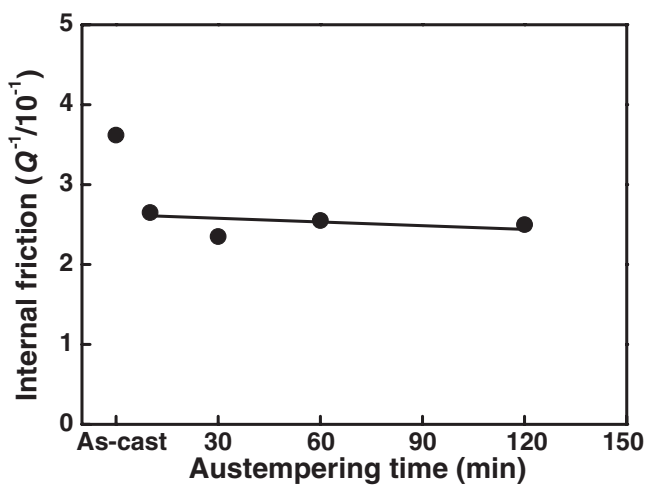

Fig. 7 Effect of austempering time on the damping capacity in austempered ductile cast irons.

austempered ductile cast iron to exhibit plastic flow in the interface between graphite and bainite microstructures, which consequently results in a drastically reduced damping capacity. In addition, although the damping capacity depends on the bainite microstructure, we did not observe a significant change in the damping capacity as the austempering treatment temperature was increased. This result suggests that the damping capacity did not significantly depend on the type of bainite microstructures obtained by various austempering treatment temperatures and the retained austenite microstructure in austempered ductile cast iron. ${ }^{13)}$ Figure 7 shows the effect of the austempering treatment time (austempering temperature $=673 \mathrm{~K}$ ) on the damping capacity in austempered ductile cast iron. It can be seen that the damping capacity did not significantly change as the austempering treatment time increased, indicating that the damping capacity of austempered ductile cast iron depends on the bainite microstructure, but not on the shape of the bainite microstructure and the retained austenite microstructure in austempered ductile cast iron.

\subsection{Effect of subzero treatment on damping capacity}

Figure 8 shows the effect of the subzero treatment temperature on the damping capacity in austempered ductile cast iron. As illustrated in Fig. 8, the damping capacity of austempered ductile cast iron dramatically increased when it was subjected to subzero treatment, and then it gradually 


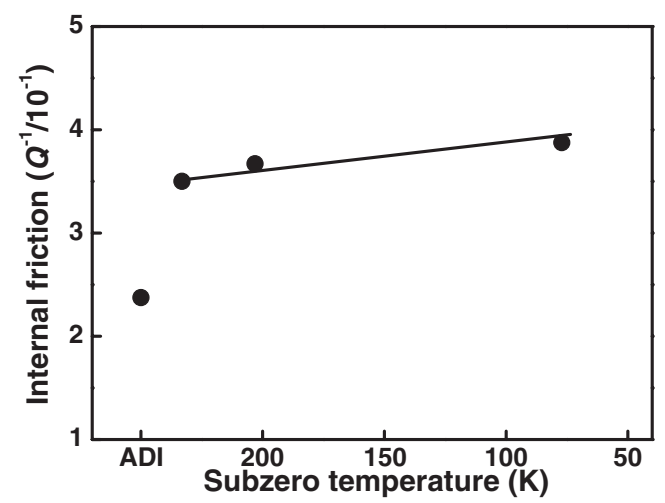

Fig. 8 Effect of subzero treatment temperature on the damping capacity in austempered ductile cast irons.

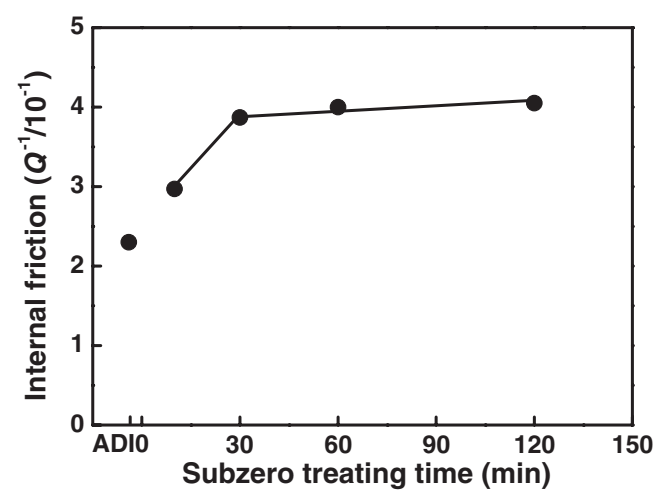

Fig. 9 Effect of subzero treatment time on the damping capacity in austempered ductile cast irons.

increased when the subzero treatment temperature was decreased. The initial increase in the damping capacity could be the result of retained austenite that was transformed into martensite by the subzero treatment. That is, it has been considered that the damping mechanism of austempered ductile cast iron was thought to be an internal friction due to the movement of the various boundaries such as stacking-fault boundaries inside martensite and austenite, martensite variant boundaries, and interfaces during vibration in an elastic region, and thereby to absorb the vibration energy. ${ }^{11)}$ It has been considered that once the martensite microstructure is formed, movement and absorption of vibrating energy occur at the interface between the martensite variant, the stacking fault, and the twin boundary inside martensite; the interface between the parent phase and martensite phase; and at other interfaces. ${ }^{11)}$ However, detailed studies on this issue have not been carried out thus far. In addition, the gradual increase in the damping capacity with the decrease in the subzero treatment temperature may be due to the formation of a greater amount of martensite transformed from the retained austenite microstructure.

Figure 9 shows the effect of the subzero treatment time on the damping capacity in austempered ductile cast iron. As the subzero treatment time increased, the damping capacity sharply increased until the subzero treatment time was $30 \mathrm{~min}$, and then it leveled off. The matrix in the austempered

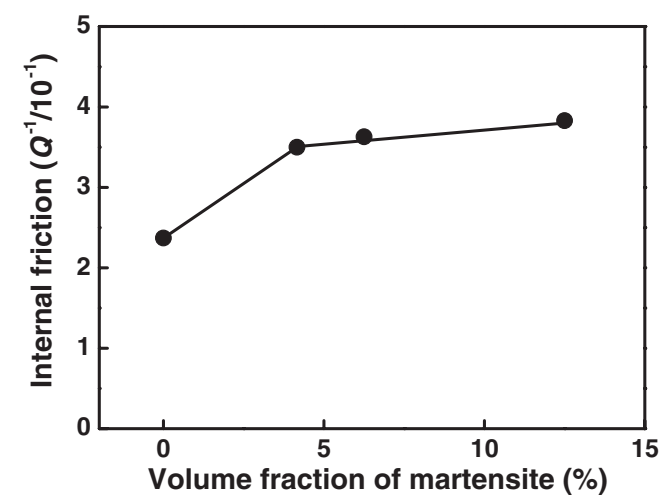

Fig. 10 Effect of volume fraction of martensite on the damping capacity obtained by subzero treatment after austempering.

ductile cast iron was transformed into a martensite microstructure by the subzero treatment. As a result, the change in the damping capacity may be due to both the retained austenite that did not transform into martensite when it was subjected to subzero treatment and the movements of the boundaries between parent and martensite phases, twin boundaries inside martensite, martensite valiant boundaries, and the stacking fault and twin boundaries inside the martensite. ${ }^{11)}$ Therefore, the damping capacity may be affected by the volume fraction of the martensite. ${ }^{12)}$ As seen in Fig. 9, when the subzero treatment time is ca. $30 \mathrm{~min}$, enough martensite is formed and thereby affects the damping capacity of the austempered ductile cast iron. However, if the subzero treatment time increases further, more martensite microstructures are formed, but they cease to affect the damping capacity, suggesting that the longer subzero treatment time ( $>30 \mathrm{~min}$ ) does not affect the damping capacity of the austempered ductile cast iron. To investigate the effect of the martensite microstructure on damping capacity in austempered ductile cast iron, the volume fraction of martensite microstructure was studied. ${ }^{12)}$ The damping capacity of the alloy is closely related to the amount of martensite and austenite microstructures, which induce damping effects via the movement of stacking fault boundaries in martensite, martensite variant boundaries, and austenite/martensite interface boundaries. Figure 10 shows the effect of volume fraction of martensite on the damping capacity obtained by subzero treatment after austempering. Figure 10 illustrates that the damping capacity increased sharply as the volume fraction of the martensite increased up to $5 \%$, beyond which it increased gradually. This result suggests that the retained austenite transformed into martensite by subzero treatment after austempering. The martensite thus formed can function as a damping source and increase internal friction, whereas dislocations occurring in both the grain boundaries and the internal microstructure of martensite can reduce the damping capacity.

\section{Conclusions}

In this work, we studied the effect of austempering and subzero treatment on the damping capacity in austempered ductile cast iron. 
The major conclusions are summarized below.

(1) The damping capacity of austempered ductile cast iron was rapidly decreased by the austempering treatment, but it was not affected by the austempering temperature and time.

(2) The retained austenite was transformed into martensite by subzero treatment of austempered ductile cast iron and was substantially transformed into martensite by decreasing the subzero treatment temperature and increasing the subzero treatment time.

(3) The damping capacity of austempered ductile cast iron was increased by subzero treatment, and it was increased by decreasing the subzero treatment temperature. As the subzero treatment time increased, the damping capacity rapidly increased until the subzero treatment time was $30 \mathrm{~min}$, after which it increased gradually.

(4) As the volume fraction of martensite increased, the damping capacity rapidly increased until the volume fraction was $5 \%$, beyond which it increased gradually.

\section{REFERENCES}

1) B. Kovacs: Proc. 2nd Int. Conf. on Austempered Ductile Iron, Ann Arbor, ML, 17-19 March, (University of Michigan, USA, 1986) pp. 291-301.

2) K. Vennemann, K. Hornung and G. Fischer: Proc. 2nd Int. Conf. on Austempered Ductile Iron, Ann Arbor, MI, 7-19 March, (University of Michigan, USA, 1986) pp. 378-389.

3) C. Y. Kang, W. J. Moon and J. H. Sung: J. Kor. Inst. Met. Mater. 35 (1997) 297-304.

4) C. Y. Kang: J. Kor. Inst. Met. Mater. 41 (2003) 8-12.

5) R. L. Miller: Trans. ASM 57 (1964) 191-199.

6) J. H. Jun and C. S. Choi: Scr. Mater. 38 (1998) 543-549.

7) Y. S. Seo, Y. K. Lee and C. S. Choi: Mater. Trans. 46 (2005) 12741277.

8) B. D. Cullity: Element of x-ray Diffraction, Appendix 7-13 (AddisonWesley, Reading, Mass. 1956).

9) G. H. Wu, Z. Y. Dou, L. T. Jiang and J. H. Cao: Mater. Lett. 60 (2006) 2945-2948.

10) Y. Watanabe, H. Sato, Y. Nishino and I. S. Kim: Mater. Sci. Eng. A 490 (2008) 138-145.

11) K. Sugimoto: Mem. Inst. Sci. Ind. Res. Osaka Univ. 35 (1978) 31-42.

12) C. Y. Kang: J. Kor. Inst. Met. Mater. 41 (2003) 8-12.

13) K. H. Lee and C. Y. Kang: J. Kor. Soc. Power System Eng. 12 (2008) $72-78$. 